\title{
Agronomic Bio-Fortification of Wheat to Combat Zinc Deficiency in Developing Countries
}

\author{
Muhammad Umair Hassan', Muhammad Aamer', Muhammad Nawaz ${ }^{2}$, Abdul Rehman ${ }^{3}$, Talha Aslam ${ }^{3}$, \\ Ubaid Afzal $^{4}$, Bilal Ahmad Shahzad ${ }^{3}$, Muhammad Ahsin Ayub ${ }^{5}$, Faryal Ahmed ${ }^{1}$, Ma Qiaoying ${ }^{1}$, Su Qitao ${ }^{1}$ \\ and Huang Guoqin ${ }^{1 *}$
}

${ }^{1}$ Research Center on Ecological Sciences, Jiangxi Agricultural University, Nanchang, 330045 China; ${ }^{2}$ Department of Agricultural Engineering, Khwaja Fareed University of Engineering and Information Technology, Rabim Yar Khan 64200, Pakistan; ${ }^{3}$ Department of Agronomy, University of Agriculture, Faisalabad, 38040, Pakistan; ${ }^{4}$ Department of Botany, University of Agriculture, Faisalabad, 38040, Pakistan; ${ }^{5}$ Rice Research Station, Babawalnagar, 62031, Pakistan.

Abstract | Zinc $(\mathrm{Zn})$ deficiency is well reported problem around the globe causing severe reduction in crop yield and quality. The intake of inadequate foods low in $\mathrm{Zn}$ is the major cause of $\mathrm{Zn}$ deficiency in humans, especially in developing countries. The deficiency of $\mathrm{Zn}$ causes many irregularties in both plants and humans. The $\mathrm{Zn}$ deficiency considerably reduced the plant growth, tillers production, chlorophyll synthesis, and crop yield. Moreover, in the case of humans' $\mathrm{Zn}$ deficiency causes blindness, lower intelligence quotient (IQ) levels, weaker immune system, and impaired physical and mental development. Wheat crop play a chief role in daily food requirement and calories need in developing countries, however, inherently wheat has lower $\mathrm{Zn}$ contents. Moreover, soil $\mathrm{Zn}$ deficiency further increasing the problem of low $\mathrm{Zn}$ contents in wheat grain. Thus, the finest way to combat the $\mathrm{Zn}$ deficiency is to produce the grains of wheat having desirable $\mathrm{Zn}$ contents at farmer's field. The breeding and agronomic (fertilizer application) bio-fortification approaches are important ones to increase $\mathrm{Zn}$ concentration in wheat grains up to desirable levels. The genetic techniques are costly, and sustainable, however, they are long term and requires large breeding activities and resources. Conversely, agronomic techniques appear to be short term, quick and economic solution to increase the $\mathrm{Zn}$ contents to meet human needs. The application of $\mathrm{Zn}$ as foliar sprays, seed priming, soil application and soil+foliar application effectively enhanced $\mathrm{Zn}$ uptake and grain $\mathrm{Zn}$ contents. $\mathrm{Zn}$ fertilization also maintains desirable $\mathrm{Zn}$ availability in soil solution and maintains the $\mathrm{Zn}$ pools in plant tissues during later stages thus resulting in an increase in $\mathrm{Zn}$ accumulation in wheat grains. Therefore, in this review, we discussed roles of $\mathrm{Zn}$ in plants and humans and possible strategies to combat $\mathrm{Zn}$ deficiency in humans. Additionally, challenges for agronomic and breeding strategies and possible benefits of both these strategies also discussed in this review.

Received | September 21, 2020; Accepted | November 21, 2020; Published | March 06, 2021

*Correspondence | Huang Guoqin, Research Center on Ecological Sciences, Jiangxi Agricultural University, Nanchang, 330045 China; Email: hgqjxes@sina.com

Citation | Hassan, M.U., M. Aamer, M. Nawaz, A. Rehman, T. Aslam, U. Afzal, B.A. Shahzad, M.A. Ayub, F. Ahmad, M. Qiaoying, S. Qitoa and H. Guoqin. 2021. Agronomic bio-fortification of wheat to combat zinc deficiency in developing countries. Pakistan Journal of Agricultural Research, 34(1): 201-217.

DOI | http://dx.doi.org/10.17582/journal.pjar/2021/34.1.201.217

Keywords | Bio-fortification, Breeding, Fertilizer application, Human's health, Wheat, Zn deficiency

\section{Introduction}

$\mathrm{C}$ Vereal crops including the wheat (Triticum aestivum) and rice (Oryza sativa) are a major source of food and nutrition for the developing nations (Cakmak, 2008). Among cereals, wheat crop is the major source of food it has chief role in the provision of nutrients, energy and proteins around the 
globe especially in the developing nations (Shewry, 2009; Chattha et al., 2017a, 2018). The wheat crop provides more than $70 \%$ daily calories to people living in the rural area, additionally, it is also a major source of micronutrients including zinc $(\mathrm{Zn})$ for the developing world (Cakmak, 2008). The consumption of wheat resulting in $\mathrm{Zn}$ deficiency owing to fact wheat crop is hereditarily lower in $\mathrm{Zn}$ and higher in phytic acid (PA) which further reduces the $\mathrm{Zn}$ bioavailability to humans (Ma et al., 2008). Additionally, wheat processing in order to make flour further diminishes $\mathrm{Zn}$ contents in flour owing to the loss of Zn during processing (Oghbaei and Prakash, 2016). $\mathrm{Zn}$ is a crucial nutrient needed for the humans and plant growth (Hafeez et al., 2013). Zn affects diverse aspect of the human's immune system (Shankar and Prasad, 1998), additionally, it is also needs for the proper and optimum functioning of cells mediating innate immunity, and natural killer cells (Prasad, 2008). $\mathrm{Zn}$ is also an imperative nutrient for plants and it plays a chief role in the plant metabolism by influencing the activity of different enzymes including carbon anhydrase (CA), and hydrogenase (Maret, 2013). Moreover, $\mathrm{Zn}$ also regulates the genes expressions and therefore, improve plant growth in stress conditions (Cakmak, 2000; Gauci et al., 2009).

Among the micro-nutrients, $\mathrm{Zn}$ deficiency is a widespread problem both in humans and plants (Welch and Graham, 2004). It has been documented that every year more than 0.5 million children under the age of 5 years died owing to $Z n$ deficiency (Black et al., 2008). $\mathrm{Zn}$ deficiency together with $\mathrm{Fe}$ and vitamin A deficiencies are considered as top priority challenges and they should be urgently tackled for humanity and global stability (WHO, 2002). Globally, more than 1.1 billion people are at the risk of $Z n$ deficiency (Kumssa et al., 2015) and this problem is more widespread in the developing countries. Moreover, percentage of the population in different areas of the world suffering from $\mathrm{Zn}$ deficiency is given in Figure 1. In different countries including Turkey, Pakistan, and Iran most of the soils are $\mathrm{Zn}$ deficient which further enhanced the $\mathrm{Zn}$ deficiency in crops and consequently in humans (Hotz and Brown, 2004). Zn deficiency is widespread problem in developing countries and particularly in those regions where people consume unbalanced foods and most of the $\mathrm{Zn}$ is lost during the making of flour owing to the fact most $\mathrm{Zn}$ is stored in the husk (Graham et al., 2001). Moreover, percentage of $\mathrm{Zn}$ uptake from animal and cereals in different regions is given in Figure 2 which is clearly describing the difference among the developing and developed nations for the $\mathrm{Zn}$ uptake from animal and cereals based food sources.

Population at Risk of Zn Deficiency (\%)

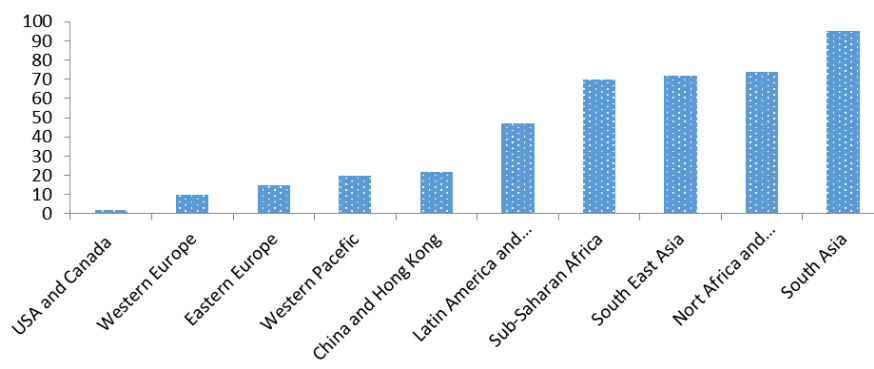

Figure 1: The percentage of populations suffering from the $\mathrm{Zn}$ deficiency in variable regions (Shabid et al., 2010).
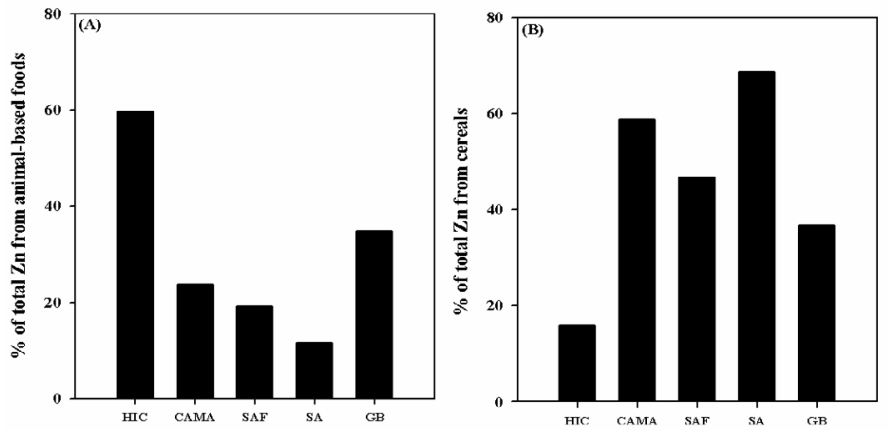

Figure 2: The \% contribution in daily $\mathrm{Zn}$ intake from and animal (A) and cereals (B) foods in different regions. HIC: High income countries, CAMA: Central Asia and Middle east, SAF: Sub-Sabaran Africa, SA: South Asia, GB: Global. Redrawn and modified from (Wessells and Brown, 2012; Cakmak and Kutman, 2018).

Bio-fortification is a novel and imperative strategy to solve the problems related to micro-nutrient deficiencies (Dennis and Ross, 2013). This strategy involves the utilization of breeding and agronomic approaches to solve the nutrient deficiency problems. The breeding approach used to develop the genotypes with higher nutrient contents are time taking and costly (Bouis et al., 2011). Conversely, agronomic strategy is a quick solution to combat the problem of $\mathrm{Zn}$ deficiency. This technique involves the application of micro-nutrients through different methods including seed treatments, soil, and foliar application (Bouis et al.,2011). The bio-fortified crops have higher concentration of nutrients and mostly wheat, rice, maize (Zea mays) potatoes (Solanum tuberosum) and beans are subjected to bio-fortification owing to the fact they are important food sources globally (Dennis and Ross, 2013). Improved human health and better crop production can be acheived by increasing the $\mathrm{Zn}$ contents in edible crops. Thus, it is the dire need of time to improve the grain $\mathrm{Zn}$ and $\mathrm{Zn}$ bio-availability 
in wheat grains in the developing world, where wheat is a staple food (Zhao and McGrath, 2009). Therefore, in this review, we discussed the roles of $\mathrm{Zn}$ for humans and plants and causes of $\mathrm{Zn}$ deficiency in wheat and possible approaches to reduce the $\mathrm{Zn}$ deficiency in humans. Additionally, role of breeding and agronomic approaches to increase wheat grain $\mathrm{Zn}$ contents in order to reduce the $\mathrm{Zn}$ deficiency in crops and humans also discussed in this review.

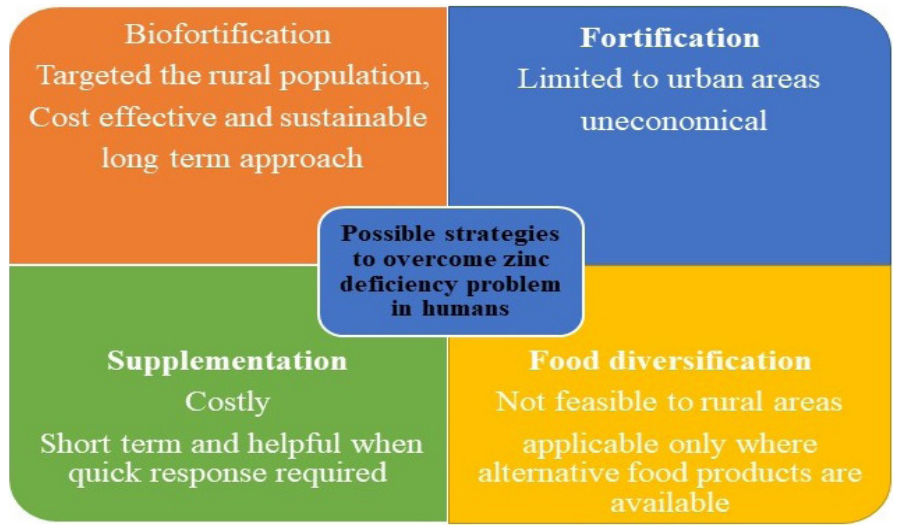

Figure 3: The possible strategies for combating $\mathrm{Zn}$ deficiency in bumans.

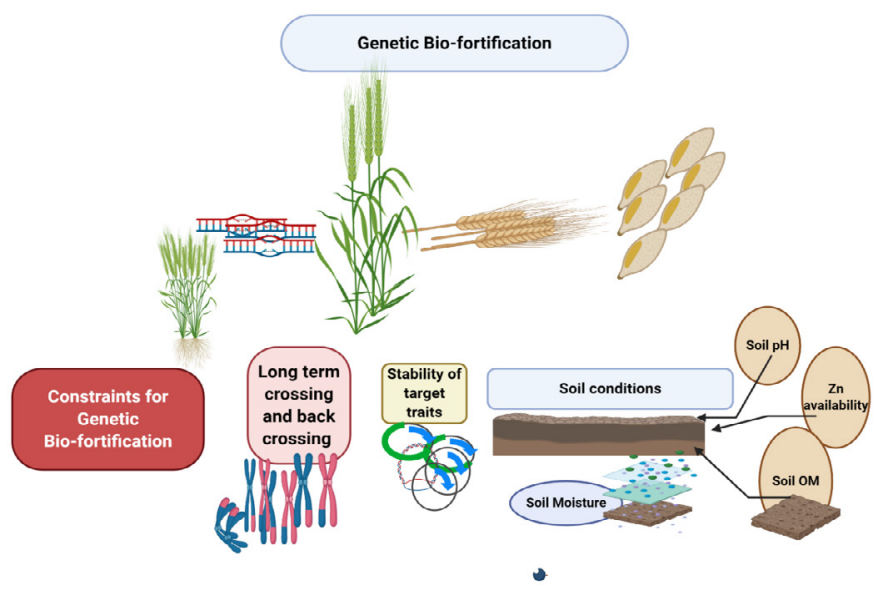

Figure 4: The constrains of breeding techniques of $\mathrm{Zn}$ biofortification.

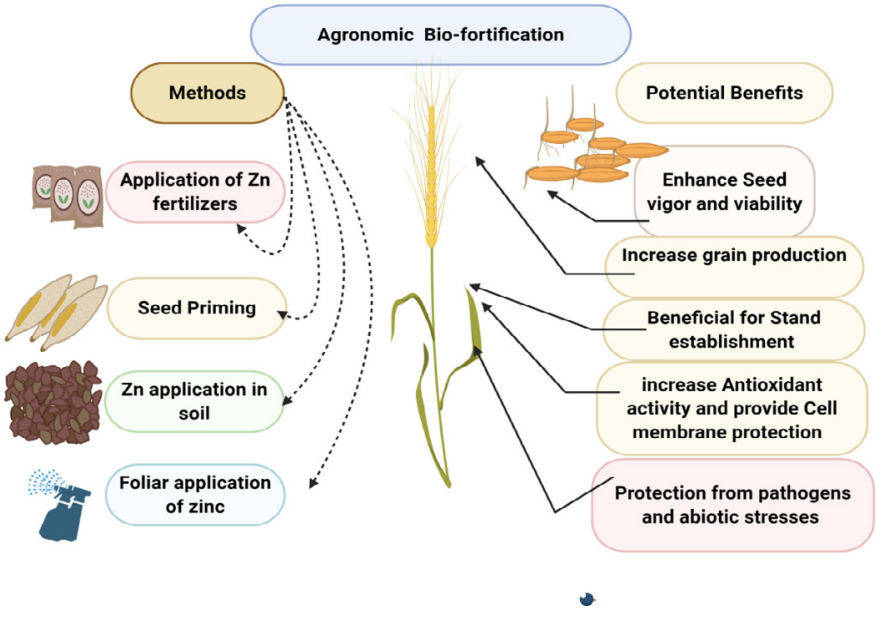

Figure 5: Potential benefits of agronomic bio-fortification of wheat.
Roles of $\mathrm{Zn}$ in plants

Zinc plays an imperative role in plant growth and development and it is considered as an important nutrient to be involved in the synthesis of proteins and amino acids (Pandey et al., 2006; Cabot et al., 2019). $\mathrm{Zn}$ also required for hormones synthesis (auxin) and its deficiency leads to a reduction in endogenous auxin and tryptophan levels, which therefore, reduced the plant growth (Pedler et al., 2000). Zn also affect activities of different enzymes including CA, hydrogenase, and fructose 1,6-bisphosphate involve in carbohydrate metabolisms. The activities of these enzymes substantially declined in $\mathrm{Zn}$ deficiency and leads to accretion of carbohydrates in leaves (Taheri et al., 2011).

$\mathrm{Zn}$ also improves nitrogen metabolism, synthesis of chlorophyll, proteins synthesis, photosynthesis and provides resistance against the stress conditions (Alloway, 2008; Mousavi, 2011; Hassan et al., 2020). Moreover, $\mathrm{Zn}$ also helps in maintaining the membrane integrity, structural arrangements of different macromolecules and also helps in the transportion of ions (Cakmak, 2008; Dang et al., 2010). The Zn deficient conditions resulting in stunted growths, and leads to reduction in tiller production and chlorophyll synthesis (Hafeez et al., 2013). Zn also improves the quality of the crops, however, $\mathrm{Zn}$ deficiency reduces the quality and increased the plant's susceptibility to diseases and temperature injuries (Hafeez et al., 2013).

\section{Roles of $\mathrm{Zn}$ in humans}

$\mathrm{Zn}$ has a key role in human health, as $\mathrm{Zn}$ influences the different features of human immune system (HIS) (Shankar and Prasad, 1998). $\mathrm{Zn}$ is essential for the cells that mediated inborn immunity (Prasad, 2008). The $\mathrm{Zn}$ supplementation in Table 1 being reduces the anemia and intestinal disturbance (Skrovanek et al., 2014) and decrease diarrhea sternness in children's (Haque and Binder, 2006). The $\mathrm{Zn}$ supplementation in humans also improves the water and electrolyte absorption (Haque and Binder, 2006) and reduce the chances of disease (sickle cell) in humans and it also affect HIS by influencing the non-specific as well as attained immunity (Bao et al., 2008).

The shortage of $\mathrm{Zn}$ in human also cause different problems including the poor functioning of the immune system, skin problems, lower IQ levels, joints pain, memory loss, night blindness and problems related to sexual maturation (Maret and Sandstead, 
2008; Wang and Busbe, 2005). However, Zn paucity in human beings can be decreased by using the bio-fortified crops enriched with micro-nutrients including Zn (Cakmak, 2002).

\section{Reasons of $Z n$ deficiency in bumans}

The deficiency of $\mathrm{Zn}$ in humans occurs owing to the utilization of foods having low $\mathrm{Zn}$ contents/ $\mathrm{Zn}$ bioavailability and diseases that impaired the intestinal absorption and resulting in an increase in intestinal Zn losses (Maria et al., 2002). Moreover, foods with high PA contents and dietary fibers further inhibit $\mathrm{Zn}$ availability and retention in humans (Foster et al., 2012).

\section{Factors associated with Zn deficiency in field crops}

The deficiency of $\mathrm{Zn}$ has been reported around the globe from temperate to arid regions (Hafeez et al., 2013). Globally, all types of soils are suffering from $Z n$ deficiency and the important factors responsible for the $\mathrm{Zn}$ deficiency in crops are discussed below.

Parent material: This is one of the most imperative factors which affects the $Z n$ availability and determines the amount of $\mathrm{Zn}$ in soils. The concentration of $\mathrm{Zn}$ in soils depends upon the waethering of rocks from which soil is derived (Alloway, 2008; Rashid and Ryan, 2008). Likewise, soil produced from granite and quart rock has low $\mathrm{Zn}$ owing to the fact these soils are sandy in nature and have poor $\mathrm{Zn}$ holding capacity (Pendies and Pendies, 1992). Conversely, soils produced from the sedimentary rock are clay in nature and have higher $\mathrm{Zn}$ content owing to better cation exchange capacity (CEC) (Alloway, 2008; Pendies and Pendies, 1992).

Soil pH: Soil $\mathrm{pH}$ greatly affects the $\mathrm{Zn}$ availability from the soil solution and soils with higher $\mathrm{pH}$ has lower $\mathrm{Zn}$ availability compared to soil with lower pH (Sadeghzadeh, 2013). Globally, most soils have $\mathrm{pH}$ above 7 and solubility of $\mathrm{Zn}$ from the soilsolution decreases with increasing the soil $\mathrm{pH}$. The upsurge in $\mathrm{pH}$ of soil ranging from 5-8 substantially decreases the $\mathrm{Zn}$ concentration from $10^{-4}-10^{-10} \mathrm{M}$ in soil solution. The higher $\mathrm{pH}$ also decreased the $\mathrm{Zn}$ availability owing to the rapid fixation of $\mathrm{Zn}$ with soil particles, aluminum and iron oxide (Imtiaz, 1999).

Restricted root zone: The modernized agriculture substantially improved crop production; however, modern practices have many disadvantages. Likewise, the soil compaction owing to the utilization of weighty machines is also a main reason for the lower $\mathrm{Zn}$ accessibility for roots to plant. The soil compactions also reduced the penetration of roots and thus reduced the $\mathrm{Zn}$ uptake which in turn negatively affect the crop production and quality (Parlak and Parlak, 2011).

Soil organic matter: The organic matter (OM) considerably affect $\mathrm{Zn}$ availability and soils with low OM have $Z n$ deficiency, whereas the soil with higher $\mathrm{OM}$ has the better $\mathrm{Zn}$ availability and solubility (Ahmad et al., 2012). Most stable constituents in soil $\mathrm{OM}$ are the humic substance, and these substances have a great attraction for the metal's ions including Zn (Kiekins, 1995). Nonetheless, soils with too much OM like peat soils also face $\mathrm{Zn}$ deficiency owing fixation of $\mathrm{Zn}$ on humic substance (Katyal and Randhawa, 1983).

Soil texture: The soil texture also has a remarkable impact on the $\mathrm{Zn}$ availability from soil to plant roots. The soils with calcareous nature have lower $\mathrm{Zn}$ availability owing rapid $\mathrm{Zn}$ fixation with soilparticles which therefore, reduced the $\mathrm{Zn}$ accessibility. Similarly, soils with course textures like sandy soils also has reduced $\mathrm{Zn}$ availability due to lower CEC and reactive sites (Hafeez et al., 2013). Conversely, fine textural soils like clay soils have higher CEC and reaction sites and therefore, they have higher $\mathrm{Zn}$ retaining capability (Singh et al., 2005). Thus, $\mathrm{Zn}$ scarcity is frequently arise in course textural soils as compared to fine texture soils (Singh et al., 2005).

Soil flooding: Soil flooding is also a major reason for Zn deficiency. Generally, $\mathrm{Zn}$ deficiency in flooded soils occurs owing to reactions of $\mathrm{Zn}$ with free sulphides (Mikkelsen and Shiou, 1977). Moreover, in flooded soil, $\mathrm{Zn}$ is also changed into sesquioxide precipitates, and theses sesquioxid binds the major part of applied $\mathrm{Zn}$ and therefore, reduce $\mathrm{Zn}$ availability (Singh and Abrol, 1986). The soil flooding also changed soil $\mathrm{pH}$ which also affects the $\mathrm{Zn}$ availability. The soil $\mathrm{pH}$ usually increased in flooded conditions which in turn reduced the $Z n$ solubility (Renkou et al., 2003). The flooded conditions also reduced the $\mathrm{Zn}$ uptake due to participation of $\mathrm{Zn}$ with $\mathrm{Fe}$ and $\mathrm{Al}$ in soil solution (Moraghan and Mascagni, 1991; Rehman et al., 2012).

Soil temperature: The lower soil temperature (ST) also leads toward $\mathrm{Zn}$ scarcity in plants (Moraghan and 
Mascagni, 1991). The microbial activities considerably reduced at low temperature which in turn reduced the release of $\mathrm{Zn}$ from OM. Moreover, lower temperature also reduced the rate of mineralization which also favors the Zn deficiency (Sadeghzadeh, 2013).

Zn interaction with other nutrients: The other soil nutrients also affect the rate of absorption, availability and utilization of $\mathrm{Zn}$ in plants. The interaction of $\mathrm{Zn}$ with $\mathrm{P}$ and nitrogen $(\mathrm{N})$ are the most-wide spread problem which reduced the $\mathrm{Zn}$ availability. The interaction of $\mathrm{Zn}$ with $\mathrm{P}$ is the main cause of $\mathrm{Zn}$ paucity in crops. The phosphorus $(\mathrm{P})$ fertilization affects the $\mathrm{Zn}$ availability from soils and $\mathrm{P}$ induces the $\mathrm{Zn}$ deficiency in plants (Singh et al., 1986). The higher $\mathrm{P}$ contents in soils either inherently or from the heavy doses of $\mathrm{P}$ application causes $\mathrm{Zn}$ deficiency (Alloway, 2008). The overdose of $\mathrm{P}$ also reduced the uptake of $\mathrm{Zn}$ owing to physiological imbalances caused in plants (Singh et al., 1986; Soltangheisi et al., 2014; Xie and Tang, 2019). The $\mathrm{P}$ induces the $\mathrm{Zn}$ deficiency occurs due to interaction of $\mathrm{Zn}$ with $\mathrm{P}$, reduction in rate of $\mathrm{Zn}$ translocation from root to shoot, and imbalance between the $\mathrm{P}$ and $\mathrm{Zn}$ that causes metabolic disorder in plants (Olsen, 1972). The higher $\mathrm{P}$ concentration in soil owing to inherent $\mathrm{P}$ or heavy $\mathrm{P}$ application reduced the $\mathrm{Zn}$ translocation and availability to plants. Moreover, in soils $\mathrm{Zn}$ and $\mathrm{P}$ also co-precipitate as the $\mathrm{ZnO}_{3}\left(\mathrm{PO}_{4}\right)^{2}$ that decreases the soil $\mathrm{Zn}$ contents thus affect the $\mathrm{Zn}$ availability to plants (Brown et al., 1970). The increase in $\mathrm{P}$ application reduces the grain, $\mathrm{Zn}$ contents owing to the reduction in $\mathrm{Zn}$ uptake (Yang et al., 2011).

The $\mathrm{N}$ addition to the soil can increase/decrease $\mathrm{Zn}$ deficiency. The $\mathrm{Zn}$ and $\mathrm{N}$ have synergetic interactions, as the application of $\mathrm{N}$ improved the crop growth. However, $\mathrm{N}$ application in the soils deficient in $\mathrm{Zn}$ further enhanced the $\mathrm{Zn}$ deficiency owing to the absorption of $\mathrm{Zn}$ due to changes in $\mathrm{pH}$ of the soil (Sadeghzadeh, 2013). The interactions of macronutrients, like, $\mathrm{Ca}, \mathrm{Mg}$ and $\mathrm{K}$ with $\mathrm{Zn}$ also inhibit the $\mathrm{Zn}$ absorption (Hafeez et al., 2013). Copper also affects the $\mathrm{Zn}$ availability, as $\mathrm{Zn}$ greatly inhibit the $\mathrm{Cu}$ absorption, whereas $\mathrm{Cu}$ affects the $\mathrm{Zn}$ redistribution in plants (Loneragan and Webb, 1993). Increase in the $\mathrm{Zn}$ application reduces the Fe uptake and accumulation in plant parts, whereas increase in Fe concentration has a depressive impact on the $\mathrm{Zn}$ contents in plant parts (Norvell and Welch, 1993).

The possible strategies for combating $\mathrm{Zn}$ deficiency in bumans

Supplementation: In this method, nutrients are given to the human being as a clinical treatment (Bouis and Welch, 2010). The $\mathrm{Zn}$ and Fe supplementations can be a quick solution during the times of higher Zn susceptibility (Gibson et al., 1998). Moreover, this practice is usually suggested in the time periods of acute $\mathrm{Zn}$ deficiency especially in pregnancy and in early childhoods (Stein et al., 2007; Allen, 1998). However, $\mathrm{Zn}$ supplementation is very costly and only suggested when we require a rapid response (Stein et al., 2007).

Fortification: The fortification involves the addition of minerals during the processing of foods to increase the nutrient contents to fulfil human needs. This strategy is recommended when $\mathrm{Zn}$ deficiency becomes endemic to target the particular areas (Maria et al., 2002). However, fortification is un-economical and typically restricted to only urban areas (Bouis and Welch, 2010; White and Broadley, 2005).

Food diversification/modification: This strategy is related to the changes in the selection of foods and making food plans more differentiated (White and Broadley, 2005). Moreover, this technique is applicable to those areas where the people have a good diversity of foods, however, this technique is not useable in developing countries where most of people live in rural areas (Bouis and Welch, 2010).

Bio-fortification: Bio-fortification is a promising Figure 3 to overcome the problem of micro-nutrition deficiency (Bouis and Welch, 2010). This technique involves the utilization of agronomic as well as breeding techniques to increase the quantity of desired nutrients in food crops (Bouis and Welch, 2010). It is an economical approach and can effortlessly target rural areas (FAO/WHO, 1998; White and Broadley, 2005). Additionally, it also substantially improved crop production in $\mathrm{Zn}$ deficit conditions (Bouis and Welch, 2010), and this approach is considered to be an permanent solution to solve the deficiency of $\mathrm{Zn}$.

\section{Genetic bio-fortification}

This technique focused on development of genotypes with higher $\mathrm{Zn}$ and lower PA contents by using the breeding techniques. In breeding approach, architecture of plants changed to ensure the maximum accretion of micro-nutrients including the $\mathrm{Fe}$ and $\mathrm{Zn}$ in cereals (Bouis, 2003). Moreover, breeding 
techniques help the plants to absorb and accumulate desirable nutrients (Bouis, 2003). This is the best way to cope with $\mathrm{Zn}$ deficiency problem by exploring the natural variations amid the genotypes and by bringing the changes in genetic makeup of plants to enhance the quantity and bio-availability of desirable micronutrients in crops (Pfeiffer and McClafferty, 2007).

In past, most important objective of breeding programs was to increase the wheat production by improving biomass, harvest indexes, and shorting the plant height (Ortiz et al., 2007; Trethowan, 2007). Similarly, grain protein contents and composition of micronutrients were equally imperative, however, often ignored. Internation maize and wheat improvement center (CIMMYT) started research on wheat crop and discovered the largest variations among the genotypes for the $\mathrm{Zn}$ contents, disease resistance and distribute varieties with higher $\mathrm{Zn}$ and $\mathrm{Fe}$ contents (Cakmak, 2008). Previously, it was documented that $\mathrm{Zn}$ and $\mathrm{Fe}$ are an inherited traits (Trethowan et al., 2005; Trethowan, 2007). The modern, as well as wild germplasms showed that $\mathrm{Zn}$ and $\mathrm{Fe}$ have the a positive association, which indicates that physiological as well as the genetic factors are involved in the $\mathrm{Zn}$ and $\mathrm{Fe}$ decomposition in seeds (Cakmak et al., 2004; GomezBecerra et al., 2010). CIMMYT focused the breeding programs on the transformation of genes involved in increasing the grain $\mathrm{Zn}$ contents from Triticum aestivum ssp. spelta and T. turgidum ssp. Dicoccon.

The transgenic approach can be the best solution to improve the grain $\mathrm{Zn}$ contents (Cakmak, 2008). It has been documented that ZIP family proteins and Fe transport proteins improve the concentraion of micronutrients in grains (Schachtman and Barker, 1999; Eide, 2006). Moreover, these proteins, appreciably increased the uptake as well as the translocation of nutrients in the plant cells. Previously different authors reported that ferritin proteins effectively improved the uptake and $\mathrm{Zn}$ accretion in grains. Similarly, transformation of ferritin genes for soybean (Glycine max) to rice increased the Fe contents (Goto et al., 1999; Qu et al., 2005). Moreover, increase in the expression of ferritin proteins increased $\mathrm{Fe}$ and $\mathrm{Zn}$ contents in transgenic plants (Drakakaki et al., 2005). The multiplexing genes in rice significantly improved $\mathrm{Zn}$ and $\mathrm{Fe}$ uptake by modifying the different pathways of uptake. The NAM-B1 transcription factors that are present in rice and wheat and different other members of the poaceae family gives point of entrance to improve the protein, $\mathrm{Fe}$ and $\mathrm{Zn}$ contents. The greater understanding of targets of NAM-B1 and transportation steps are the vital points that can help to engineer the pattern of expression down-streaming targets in order to improve the grain $\mathrm{Zn}$ contents (Distelfeld et al., 2012). Modern technologies have helped us to develop the lines with NAM-B1 which helps to regulate the $\mathrm{Zn}$ and $\mathrm{Fe}$ uptakes (Cantu et al., 2011). Recently it was documented that Gpc-B1 locus from Triticum diccocoides encodes NAC transcriptions factor (NAM-B1) that appreciably improves the grain $\mathrm{Zn}$ by remobilizing $\mathrm{Zn}$ from plant leaves to grains (Uauy et al., 2006). However, the decrease in NAM genes expression declined the $\mathrm{Fe}$ and $\mathrm{Zn}$ accumulation in grains (Uauy et al., 2006).

The use of molecular markers is also a promising approach for the identifications of plants with higher $\mathrm{Zn}$ and $\mathrm{Fe}$ concentrations. Some authors identified that quantitative trait loci (QTL) associated with $\mathrm{Zn}$ in cereal crops and revealed that wild emmer wheat has the higher allelic diversities for the $\mathrm{Fe}$ and $\mathrm{Zn}$ (Xie and Nevo, 2008). Peleg et al. (2009) did the mapping of 82 QTLs for the ten diverse nutrients and they noticed that most of positive alleles are donated by wild emmer wheat. Moreover, TtNAM-B1 genes, originated from $T$. dicoccoides have been cloned and they substantially affected the $\mathrm{Zn}$ and Fe contents (Distelfeld et al., 2007). In diploid wheat, one QTL for $\mathrm{Zn}$ on chromosome A7 and two QTLs for Fe on chromosome on A2 have been identified (Tiwari et al., 2009). Similarly, a QTL in wheat (T. monococum) on chromosome $5 \mathrm{~B}$ linked with $\mathrm{Zn}, \mathrm{Fe}, \mathrm{Mn}$ abd $\mathrm{Cu}$ has been also identified (Ozkan et al., 2006) and four QTLs for the grain $\mathrm{Zn}$ have been also identified in double haploid wheat for the grain $\mathrm{Zn}$ (Genc et al., 2009).

Constrains to genetic bio-fortification: There is no doubt that breeding practices are a sustainable and long-term approach to adress the problems of $\mathrm{Zn}$ deficiency. Nonetheless, this technique is time taking and substantially needs large resources as well as breeding activities (Cakmak, 2008). Moreover, success of any newly produced genotype largely depends upon the availability of $\mathrm{Zn}$ pools in the soil. Additionally, high pool of $\mathrm{Zn}$ should be maintained in soils for having the desirable grain $\mathrm{Zn}$ (Cakmak, 2008). The $\mathrm{Zn}$ deficiency is well-known problem around the globe and it has been documented more than $50 \%$ of soils used for the growing of cereals are $\mathrm{Zn}$ deficient 
and have low $\mathrm{Zn}$ availability (Cakmak, 2002). The $\mathrm{Zn}$ availability in soils depends upon soil $\mathrm{pH}$ and increase in $\mathrm{pH}$ (5.5-7.0) resulting in a reduction of more than 30-45 folds in Zn availability (Marschner, 1995).

Similarly, soil OM also affects the stability of newly produced genotypes. The OM play a considerable role in $\mathrm{Zn}$ Figure 4 and solubility from soil to the roots of plant (Obrador et al., 2003). The low OM in soil resulting in $\mathrm{Zn}$ deficiency, whereas the higher OM substantially improved the $\mathrm{Zn}$ availability (Hafeez et al., 2013). Most of soil used around the globe have lower $\mathrm{OM}$ which induced $\mathrm{Zn}$ deficiency in cereals (White and Zasoski, 1999; Alloway, 2004) and resulting in production of grains with poor $\mathrm{Zn}$ content. Therefore, genetic capabilities of newly evolved genotypes to absorb the required quantity of $\mathrm{Zn}$ from the soil to accumulate it in grains cannot be fully expressed in soils with lower $\mathrm{Zn}$ availability (Cakmak, 2008).

The transportation of $\mathrm{Zn}$ from the soil to roots occurs due to diffusion, therefore, soil moisture plays a crucial role in $\mathrm{Zn}$ diffusion from soil solution to roots (Cakmak, 2008). The drought stres adversely affects $\mathrm{Zn}$ nutrition in plants especially in those areas where the top soil is mostly dried in later parts of the growing period (Cakmak, 2008). Thus, in the aforementioned circumstances; agronomic bio-fortification can offer a rapid solution to cope with the problem of $\mathrm{Zn}$ deficiency (Bouis et al., 2011).

\section{Agronomic bio-fortification}

The fertilizers application susbtantially increased the grain $\mathrm{Zn}$ contents and it can be quick solution to combat the problem of $\mathrm{Zn}$ deficiency. Additionally, this approch also improves the $Z n$ availability, crop growth, and grain yield and grain $\mathrm{Zn}$ concentration (Yadav et al., 2011).

Forms of $\mathbf{Z n}$ fertilizers: $Z$ inc can be applied to crops in organic and as well as in inorganic form (Cakmak, 2008). The variable $Z n$ fertilizers are using around the globe to alleviate $\mathrm{Zn}$ deficiency and to increase the grain $\mathrm{Zn}$ (Shahid et al., 2010). $\mathrm{ZnSO}_{4}$ is mostly using $\mathrm{Zn}$ fertilizer owing to its higher solubility and lower cost (Shahid et al., 2010). Moreover, $\mathrm{Zn}$ can also be used in the forms of $\mathrm{ZnO}, \mathrm{ZnEDTA}$ and $\mathrm{Zn}$-oxysulfate. The agronomic efficiencies of $\mathrm{Zn}$ fertilizer with Zn-EDTA are quite higher, however, their higher cost mostly restricts their use for cereals production (Cakmak, 2008).

Methods of $Z \mathbf{n}$ application: The variable methods of $\mathrm{Zn}$ application are used globally, however, sucess of any application method largely depend upon the soil and socio-economic factors (Cakmak, 2009). Most of the farmers do not use the $\mathrm{Zn}$ for cereals production owing to economic problems in developing countries (Shahid et al., 2010). Moreover, poor information, financial constraints and un-availability of $\mathrm{Zn}$ products are the major causes for slower adaptation towards the $\mathrm{Zn}$ application (Bell and Dell, 2008). The methods of $Z n$ application have a significant impact on the production and grain $\mathrm{Zn}$ contents. Therefore, method of application must be farmer friendly and economical (Shahid et al., 2010).

Seed priming: Seed priming $(\mathrm{SP})$ refers to soaking of seeds in water prior to sowing until processes related to germinations start, but radical does not emerge (Farooq et al., 2009). The SP with $\mathrm{Zn}$ fertilizers significantly increased the wheat production and $\mathrm{Zn}$ uptake by the seeds (Kang and Okoro, 1976). Moreover, SP with $\mathrm{ZnSO}_{4}(0.4 \%)$ effectively met the $\mathrm{Zn}$ needs of wheat and substantially increased the grain yield by more than 21\% compared to no SP (Harris et al., 2007). Additionally, SP with $\mathrm{Zn}$ also improved seed $\mathrm{Zn}$ by more than $12 \%$ in wheat $29 \%$ in chickpea (Harris et al., 2007). Likewise, in another study, on rice, it was reported $\mathrm{Zn}$ priming was more economical and it led to a considerable increase in production and grain $\mathrm{Zn}$ (Slaton et al., 2005). Moreover, Yilmaz et al. (1997) noticed that SP with $\mathrm{Zn}$ effectively increased the wheat yield in $Z n$ deficient soil, however, it had no impact on grain $\mathrm{Zn}$. The $\mathrm{SP}$ with $\mathrm{Zn}$ is cost-effective, environment friendly and it resulting in a significant increase in the yield, and in rare cases, $\mathrm{SP}$ proved to a non-beneficial method (Farooq et al., 2012).

Soil application of $\mathbf{Z n}$ : The deficiency of $\mathrm{Zn}$ causes a considerable reduction in crop production and grain $\mathrm{Zn}$ contents nonetheless, $\mathrm{Zn}$ deficiency can be alleviated by $\mathrm{Zn}$ application. The soil application of nutrients is considered as the best method for the continuous nutrients supply when nutrients are needed in larger quantities. The high $\mathrm{Zn}$ application is mostly recommended for those crops which are quite sensitive against the $\mathrm{Zn}$ deficient conditions (Martens and wester, 1991). The banding placement of $Z n$ requires 3 times less $\mathrm{Zn}$ requirements compared to broadcasting (Sarwar et al., 2017). Moreover, in soil application it is 
quite difficult to uniformly distribute the $\mathrm{Zn}$ on the soil which resulting in loss of nutrients and increases the cost of production (Savithri et al., 1999).

In an investigation, Cakmak et al. (2010) noticed that soil applied $\mathrm{Zn}$ was beneficial to increase the yield, however, soil application was less effective to improve the grain $\mathrm{Zn}$ compared to foliar application owing to low fertilizer use efficiency (FUE). Soil applied $\mathrm{Zn}$ also effectively improved the grain $\mathrm{Zn}$ contents, however, owing to lower FUE this method requires higher application of fertilizers (Singh, 2007). Zou et al. (2012) performed investigations in different countries and noticed that soil applied appreciable increased the grain yield, however, foliar feeding was superior for increasing the grain $\mathrm{Zn}$ compared to soil application. In another study, Chattha et al. (2017b) also claimed soil+foliar application was more effective to increase the grain production and $\mathrm{Zn}$ contents, compared to alone soil and foliar application.

Foliar application of $\mathbf{Z n}$ : The foliar feeding of micronutrients effectively improves the grain $\mathrm{Zn}$ owing to the fact in this application method the loss of nutrients is very low and nutrients are directly absorbed by plants (Johnson et al., 2005). The foliar-applied $\mathrm{Zn}$ is very effective in increasing the grain $\mathrm{Zn}$ and $\mathrm{Zn}$ bioavailability (Hussain et al., 2012; Zhang et al., 2012). Zinc is immobile in plants and $\mathrm{Zn}$ application in higher concentrations is also toxic for plants therefore, $\mathrm{Zn}$ should be used as repeated sprays to overcome $\mathrm{Zn}$ deficiency. The foliar applied $\mathrm{Zn}$ at the later growth stages significantly increased the grain $\mathrm{Zn}$ contents (Yilmaz et al., 1997). The $\mathrm{Zn}$ application in the form of SP and foliar feeding appreciable increased the grain $\mathrm{Zn}$ contents and the increase in grain $\mathrm{Zn}$ reduced the PA contents which in turn increases the Zn bio-availability (Cakmak, 2008).

The foliage feeding is most important and curative method for combating the $\mathrm{Zn}$ deficiency in cereals. Moreover, in arid as well as the semi-arid areas the foliar application is considered as a special application method due to increase in direct $\mathrm{Zn}$ absorption (Chapagan and Wiesman, 2004). The foliar feeding is considered as an economical method, however, sometimes it becomes un-economical owing to the repetition of spray during the crops growing period. The foliar feeding of $\mathrm{Zn}$ alone or in combination with other micronutrients improved yield traits, grain production and grain quality (Maralian, 2009).
The foliar feeding is more effective in increasing the $\mathrm{Zn}$ contents in grain and flour than the soil application, even though a small quantity of $\mathrm{Zn}$ is used in foliar feeding equated to soil applied $\mathrm{Zn}$ (Cakmak et al., 2010). Moreover, soil application is less effective due lower mobility of $\mathrm{Zn}$ and its quick fixation with soil particularly in alkaline and calcareous soils (Alloway, 2008). The soil application has another problem; the roots of wheat and applied $\mathrm{Zn}$ have diverse distributions in soil profile which declines the $\mathrm{Zn}$ uptake by roots of the plant (Holloway et al., 2010). Additionally, in field top soil layer is dry during later growth stages (reproductive stages) and root activity also declined during these stages owing to less allocation of photosynthates. Thus, $\mathrm{Zn}$ uptake from soil substantially decreased during this stage which in turn reduced the $\mathrm{Zn}$ accumulation in grains (Zhang et al. 2010). The foliar feeding of $\mathrm{Zn}$ during the later growth stages maintain the higher pool of $\mathrm{Zn}$ and contributes appreciably towards the bio-fortification of wheat crop (Cakmak, 2008; Cakmak et al., 2010).

\section{Benefits of agronomic bio-fortification: The} fertilization strategy is a quick and economical solution for combating the $\mathrm{Zn}$ deficiency (Bouis and Welch, 2010). The exogenously applied $Z$ n not only increases the grain production and grain $\mathrm{Zn}$ but also resulting in Figure 5. The $\mathrm{Zn}$ application effectively reduced $\mathrm{P}$ uptake as well as the accretion in seeds (Soltangheisi et al., 2014). The PA is an important component that limit the Zn bio-availability (Gibson, 2007; Hotz and Gibson, 2007) and it has been documented that 60-85\% $\mathrm{P}$ present in the form $\mathrm{PA}$ in seeds which limits the Zn bio-availability (Gibson, 2006). Thus, $\mathrm{Zn}$ application reduced the accretion of $\mathrm{PA}$ in seeds which in turns increases $\mathrm{Zn}$ bio-availability in humans (Cakmak, 2008).

The exogenous applied $\mathrm{Zn}$ increased the stand establishment (Yilmaz et al., 1997) and no Zn application resulting in poor stand establishment, vigor and poor final grain production (Yilmaz et al., 1998). Additionally, sowing of seeds with higher $\mathrm{Zn}$ concentration, improves the seed viability, seed vigor, and grain production and reduces seed rates for sowing of crops (Rengel and Graham, 1995; Cakmak, 2008). Moreover, high $\mathrm{Zn}$ contents, also protect the plants from pathogens and abiotic stresses owing to fact $\mathrm{Zn}$ protect the cell membrane and increase the activities of the anti-oxidant system (Cabot et al., 2019; Rehman et al., 2012). 
Table 1: Zn requirements for human beings.

Age

Infants of three months to 3 years children 3

4-7 years children

9-13 years children

Adult humans

Pregnant females

Females in lactation period

FAO/WHO, 2002; Hotz and Brown, 2004.

The success stories of agronomic bio-fortification in different countries during the recent years

The concentrating of $\mathrm{Zn}$ in wheat ranged from 5 to $12 \mathrm{mg} / \mathrm{kg}$ in $\mathrm{Zn}$ deficient soils (Erdal et al., 2002). Moreover, on the basis of different studies, it was reported that average $\mathrm{Zn}$ contents in wheat grain vary from 20 to $35 \mathrm{mg} / \mathrm{kg}$ (Rengel et al., 1999; Graham et al., 2007; Fardet et al., 2008; Cakmak et al., 2010; Cakmak and Kutman, 2018). These Zn concentrations are not sufficient to meet daily needs of people particularly for those people who consume a large quantity of cereals-based products. Thus, for having desirable effects on human health, agronomic bio-fortification should increase the grain $\mathrm{Zn}$ contents by more the $40-50 \mathrm{mg} / \mathrm{kg}$ (Cakmak, 2008; Zhao et al., 2009). The agronomic bio-fortification is widely using in different regions of the world and this strategy significantly increasing the grain $\mathrm{Zn}$ contents. The findings of different authors are described in the Table 2, which is indicating the success of this strategy. Moreover, in all discussed studies agronomic bio-fortification considerably increased the grain $\mathrm{Zn}$ contents to meet the needs of humans.

\section{Concluding remarks and future prospects}

The deficiency of $\mathrm{Zn}$ in humans causes many health problems, including stunted growth, lower IQ level, birth problem, poor sexual maturation and reduction in efficiency of the immune system. The use of cerealbased products lower in the $\mathrm{Zn}$ are main cause of $\mathrm{Zn}$ deficiency, particularly in developing countries. The bio-fortification strategies including breeding and fertilizer application can be a viable solution to combat the $\mathrm{Zn}$ deficiency in humans. Breeding techniques are long term process, not economical and require larger resources. Conversely, agronomic bio-fortification of wheat is a promising approach which appreciably enhanced the grain production and grain $\mathrm{Zn}$ up to the desired level to meet the human needs. The application of $\mathrm{Zn}$ fertilizers as seed priming, soil and foliar application and as well as soil+foliar application effectively enhanced the grain production and grain $\mathrm{Zn}$ contents. Various abiotic stresses negatively affect the growth and productivity of wheat crop, and these stresses also change the nutritional profiles of wheat grains. The seeds enriched with $\mathrm{Zn}$ contents can with stand the adverse conditions and show improved adaption and production under stress conditions. Moreover, in future more studies are direly needed to discover the efficient methods of $\mathrm{Zn}$ application for increasing the uptake and accumulation of $\mathrm{Zn}$ in wheat grains to meet human needs. Additionally, more studies should be focused on to increase the $\mathrm{Zn}$ concentration and bio-availability which can be accomplished by increasing the grain $\mathrm{Zn}$ contents and reducing the grain phytic acid contents.

Table 2: The success stories of agronomic bio-fortification.

Country Yea

China

$2012 \quad 37.1$

China

201931.4

India

$2010 \quad 24.9$

India

$2013 \quad 24.23$

Kazakhstan 201020.0

Pakistan $2017 \quad 33.7$

Pakistan 201935.3

Turkey $\quad 2010 \quad 30.1$

Turkey

201012

Zambia

$2010 \quad 23.0$
Methods of $Z n$ application

$\begin{array}{llll}\text { NDA } & 38.9 & 46.01 & \text { NDA } \\ \text { NDA } & \text { NDA } & 60.35 & \text { NDA } \\ \text { NDA } & 52.0 & 64.8 & 65.3 \\ \text { NDA } & 21.93 & \text { NDA } & 36.75 \\ \text { NDA } & 26.0 & 73.0 & 91.0 \\ 39.45 & 46 & 60.15 & 62.7 \\ 40.92 & 49.7 & 60.92 & \text { NDA } \\ \text { NDA } & 30.6 & 43.0 & 44.8 \\ \text { NDA } & 18 & \text { NDA } & 35 \\ \text { NDA } & 24.0 & \text { NDA } & 43.0\end{array}$

\section{Reference}

(Yue et al., 2012)

(Ning et al., 2019)

(Zou et al., 2012)

(Bharti et al., 2013)

(Zou et al., 2012)

(Chattha et al. 2017b)

(Hassan et., 2019)

(Zou et al., 2012)

(Cakmak et al., 2010)

(Zou et al., 2012)

NDA: No data available. 
Acknowledgements

This work was supported by the National Key R and D Program of China (2016YFD0300208); National Natural Science Foundation of China (41661070); Key disciplines (construction) of ecology in the 13th Five-Year Plan of Jiangxi Agricultural University.

\section{Novelty Statement}

Zinc deficiency is wide spread problem in humans and plants. Therefore, in this review we discussed role of breeding and agronomic approaches to increase wheat grain $\mathrm{Zn}$ contents in order to reduce the $\mathrm{Zn}$ deficiency in crops and humans. Additionally, we also recommended future suggestions to improve the grain $\mathrm{Zn}$ contents of wheat for combating $\mathrm{Zn}$ deficiency.

\section{Author's Contribution}

Muhammad Umair Hassan: Conceived the idea and write original draft.

Muhammad Aamer, Muhammad Nawaz, Abdul Rehman, Talha Aslam and Ubaid Afzal: Writing, review and editing.

Bilal Ahmad Shahzad, Muhammad Ahsin Ayub and Faryal Ahmed: Review and editing.

Ma Qiaoying and Su Qitao: Writing, review and editing and literature collection.

Huang Guoqin: Conceived the idea and funding acquisition.

\section{Conflict of interest}

The authors have declared no conflict of interest.

\section{References}

Ahmad, W., M.J. Watts, M. Imtiaz, I. Ahmed and M.H. Zia. 2012. Zinc deficiency in soils, crops and humans: A review. Agrochm. pp. 65-97. https://doi.org/10.5772/36702

Alloway, B.J., 2004. Zinc in soils and crop nutrition. International Zinc Association Communications. IZA Publications, Brussel.

Alloway, B.J., 2008. Micronutrients and crop production. In micronutrient deficiencies in global crop production. 1-39@ Springer Science Business Media BV. https://doi. org/10.1007/978-1-4020-6860-7_1

Allen, L.H., 1998. Zinc and micronutrient supplements for children. Am.J. Clin. Nutr., 68:

495. https://doi.org/10.1093/ajcn/68.2.495S

Bao, B., A.S. Prasad, F.W. Beck, D. Snell, A. Suneja, F.H. Sarkar, N. Doshi, J.T. Fitzgeral and P. Swerdlow. 2008. Zinc supplementation decreases oxidative stress, incidence of infection, and generation of inflammatory cytokines in sickle cell disease patients. Trans. Res., 152: 6780. https://doi.org/10.1016/j.trs1.2008.06.001

Bharti, K., N. Pandey, D. Shankhdhar, P.C. Srivastava and S.C. Shankhdhar. 2013. Improving nutritional quality of wheat through soil and foliar zinc application. Plant Soil Environ., 59(8): 348-352. https://doi. org/10.17221/158/2013-PSE

Bouis,H.E.,C.Hotz,B.McClafferty,J.V.Meenkashi and W.H. Pfeiffer. 2011. Biofortification: A new tool to reduce micronutrient malnutrition. Food Nutr. Bull., 32: S31-S40. https://doi. org/10.1177/15648265110321S105

Bouis,H.E.and R.M.Welch.2010.Biofortification: A sustainable agricultural strategy for reducing micronutrient malnutrition in the global south. Crop Sci., 50: S20-S32. https://doi. org/10.2135/cropsci2009.09.0531

Bell, R.W. and B. Dell. 2008. Micronutrients for sustainable food, feed, fibre and bioenergy production. International Fertilizer Industry Association, Paris, France. pp. 36-57.

Black, R.E., H.A. Lindsay, Z.A. Bhutta, L.E. Caulfield, D.M. Onnis, M. Ezzati, C. Mathers and J. Rivera. 2008. Maternal and child undernutrition: Global and regional exposures and health consequences. Lancet, 371: 243-260. https://doi.org/10.1016/S01406736(07)61690-0

Bouis, H.E., 2003. Micronutrient fortification of plants through plant breeding: Can it improve nutrition in man at low cost. P. Nutr. Soc., 62: 403-411. https://doi.org/10.1079/ PNS2003262

Brown, A.L. and B.A. Krantz. 1970. Edding JL. Zinc-phosphorus interaction as measured by plant response and soil analysis. Soil Sci., 110: 415-420. https://doi.org/10.1097/00010694197012000-00009

Cantu, D., S.P. Pearce, A. Distelfeld, M. Christiansen, W. Uauy and C. Akhunov. 2011. Effect of the down-regulation of the high Grain Protein Content (GPC) genes on the wheat transcriptome during monocarpic 
senescence. BMC Genom., 12: 492. https://doi. org/10.1186/1471-2164-12-492

Cakmak, I., M. Kalayci, Y. Kaya, A.A. Torun, N. Aydin, Y. Wang, Z. Arisoy, H. Erdem, A. Yazici, O. Gokmen, L. Ozturk and W.J. Horst. 2010. Biofortification and localization of zinc in wheat grain. J. Agric. Food Chem., 58: 90929102. https://doi.org/10.1021/jf101197h

Cakmak, I., 2009. Enrichment of fertilizers with zinc: An excellent investment for humanity and crop production in India. J. Trace Elem. Med. Biol., 23: 281-289. https://doi.org/10.1016/j. jtemb.2009.05.002

Cakmak, I., 2008. Enrichment of cereal grains with zinc: Agronomic or genetic biofortification. Plant Soil, 302: 1-17. https://doi.org/10.1007/ s11104-007-9466-3

Cakmak, I., 2002. Plant nutrition research priorities to meet human needs for food in sustainable ways. Plant Sci., 247: 3-24. https:// doi.org/10.1007/978-94-017-2789-1_1

Cakmak, I., 2000. Role of zinc in protecting plant cells from reactive oxygen species. New Phytol., 146: 185-205. https://doi.org/10.1046/j.14698137.2000.00630.x

Cakmak, I., A. Torun, E. Millet, M. Feldman, M. Fahima, T. Korol, A. Nevo, E. Braun and H.J. Ozkan. 2004. Triticum dicoccoides: An important genetic resource for increasing zinc and iron concentration in modern cultivated wheat. J. Plant Nutr. Soil Sci., 50: 1047-1054. https://doi.org/10.1080/00380768.2004.10408 573

Cakmak, I. and U.B. Kutma. 2018. Agronomic biofortification of cereals with zinc: A review. Eur.J. Soil Sci., 69(1): 172-180. https:// doi.org/10.1111/ejss.12437

Chattha, M.U., M.U. Hassan, I. Khan, M.B. Chattha, A. Mahmood, M.U. Chattha, M. Nawaz, M.N. Subhani, M. Kharal and S. Khan. 2017b. Biofortification of wheat cultivars to combat zinc deficiency. Front. Plant Sci. 8: 281. https://doi.org/10.3389/fpls.2017.00281

Chattha, M.U., M.B. Chattha, I. Khan, U. Anwar, M.U. Hassan, M. Nawaz, S.S. Anjum, A. Mahmood and S. Mirza.2017. Effect of seeding rate and seed soaking duration on productivity of relay-intercropped wheat in cotton. Pak. J. Sci., 69(2): 190-194.

Chattha,M.U.,H.Ali,M.U.Chattha,M.U.Hassan, M.B. Chattha, M. Nawaz and S. Hussain. 2018.
Combined application of distillery spent wash, bio-compost and inorganic fertilizers improves growth, yield and quality of wheat. J. Anim. Plant Sci. 28: 1112-1120.

Chapagain, B.P. and Z. Wiesman. 2004. Effect of Nutri-Vant-Peak foliar spray on plants development, yield, and fruit quality in green house tomatoes. Sci. Hortic., 102: 177-188. https://doi.org/10.1016/j.scienta.2003.12.010

Cabot, C., S. Martos, M. Llugany, B. Gallego, R. Tolrà and C. Poschenrieder. 2019. A role for Zinc in plant defense against pathogens and herbivores. Front. Plant Sci., 10: 1171. https:// doi.org/10.3389/fpls.2019.01171

Dennis, D.M. and R.M. Welch. 2013. Food system strategies for preventing micronutrient malnutrition. ESA Working Paper No. 13-06. FAO August, 2013.

Dennis, M.D. and M.W. Ross. 2013. Food system strategies for preventing micro-nutrient malnutrition. Food Policy, 42: 115-128.

Distelfeld, A., S. Pearce, R. Avni, B. Scherer and U.C. Piston. 2012. Divergent functions of orthologous NAC transcription factors in wheat and rice. Plant Mol. Biol., 78: 515-524. https://doi.org/10.1007/s11103-012-9881-6

Dang, H.R., Y. Li, X. Sun and L.Y. Zhang. 2010. Absorption, accumulation and distribution of zinc in highly-yielding winter wheat. Agric. Sci. China, 9(7): 965-973. https://doi.org/10.1016/ S1671-2927(09)60178-4

Distelfeld, A., I. Cakmak, Z. Peleg, L. Ozturk, A.M. Yazici and H. Budak. 2007. Multiple QTL-effects of wheat Gpc-B1 locus on grain protein and micronutrient concentrations. Physiol. Plantarum., 129: 635-643. https://doi. org/10.1111/j.1399-3054.2006.00841.x

Drakakaki, G., S. Marcel, R.P. Glahn, L. Lund, S. Periagh, R. Fischer, P. Christou and E. Stoger. 2005. Endosperm specific co-expression of recombinant soybean ferritin and Aspergillus phytase in maize results in significant increases in the levels of bioavailable iron. Plant Mol. Biol., 59: 869-880. https://doi.org/10.1007/ s11103-005-1537-3

Eide, D.J., 2006. Zinc transporters and the cellular trafficking of zinc. Biochim. Biophy. Acta, 1763: 711-722. https://doi.org/10.1016/j. bbamcr.2006.03.005

Erdal, I., A. Yilmaz, S. Taban, S. Eker and I. Cakmak. 2002. Phytic acid and phosphorus 
concentrations in seeds of wheat cultivars grown with and without zinc fertilization. J. Plant Nutr., 25: 113-127. https://doi.org/10.1081/ PLN-100108784

Fardet, A., E. Roc and C. Remesy. 2008. Is the in vitro antioxidant potential of whole-grain cereals and cereal products well reflected in vivo? J. Cereal Sci., 48: 258-276. https://doi. org/10.1016/j.jcs.2008.01.002

Farooq, M., S.M.A. Basra, A. Wahid, A. Khaliq and N. Kobayashi. 2009. Rice seed invigoration. In: E. Lichtfouse (Ed.). Sustainable Agriculture Reviews, Springer, the Netherlands. https://doi. org/10.1007/978-1-4020-9654-9_9

Farooq, M., A. Wahid and K.H.M. Siddique. 2012. Micronutrients application through seed treatments. A review. J. Soil Sci. Plant Nutr., 12: 125-142.

FAO/WHO, 1998. Vitamin and Mineral Requirements in Human Nutrition, $2^{\text {nd }}$ edition. Joint FAO/WHO expert consultations, Bangkok, Thailand.

Foster, M., M. Karra, T. Picone, A. Chu, D.P Hancock, P. Petocz and S. Samman. 2012. Dietary fiber intake increases the risk of zinc deficiency in healthy and diabetic women. Biol. Trace Elem. Res., 149(2): 135-142. https://doi. org/10.1007/s12011-012-9408-7

Gauci, V.J., A.G. Beckhouse, V. Lyons, E.J. Beh, P.J. Rogers, I.W. Dawes and V.J. Higgins. 2009. Zinc starvation induces a stress response in Saccharomyces cerevisiae that is mediated by the Msn2p and Msn4p transcriptional activators. FEMS Yeast Res., 9(8): 1187-1195. https:// doi.org/10.1111/j.1567-1364.2009.00557.x

Gomez-Becerra, H.F., H. Erdem, A. Yazici, Y. Tutus, B. Torun, O. Ozturk and I. Cakmak. 2010. Grain concentrations of protein and mineral nutrients in a large collection of spelt wheat grown under different environments. J. Cereal Sci., 52: 342-349. https://doi.org/10.1016/j. jcs.2010.05.003

Genc, Y., A.P. Verbyla, A.A. Torun, I. Cakmak, K. Willsmore, H. Wallwork and G.K. McDonald. 2009. Quantitative trait loci analysis of zinc efficiency and grain zinc concentration in wheat using whole genome average interval mapping. Plant Soil, 314: 49-66. https://doi.org/10.1007/ s11104-008-9704-3

Gibson, R.S., 2007. The role of diet- and hostrelated factors in nutrient bioavailability and thus in nutrient-based dietary requirement estimates. Food Nutr. Bull., 28: 77-100. https:// doi.org/10.1177/15648265070281S108

Gibson, R.S. 2006. Zinc: The missing link in combating micronutrient malnutrition in developing countries. Proc. Nutr. Soc., 65: 5160. https://doi.org/10.1079/PNS2005474

Graham, R.D., R.M. Welch and H.E. Bouis. 2001. Addressing micronutrient malnutrition through enhancing the nutritional quality of staple food, principles, perspectives and knowledge gaps. Adv. Agron., 70: 77-142. https://doi. org/10.1016/S0065-2113(01)70004-1

Graham, R.D., R.M. Welch, D.A. Saunders, L. Ortiz-Monasterio, H.E. Bouis and M. Bonierbale. 2007. Nutritious subsistence food systems. Adv. Agron., 92: 1-74. https://doi. org/10.1016/S0065-2113(04)92001-9

Goto, F., T. Yoshihara, N. Shigemoto, S. Toki and F. Takaiwa. 1999. Iron fortification of rice seed by the soybean ferritin gene. Nat. Biotechnol., 17: 282-286. https://doi.org/10.1038/7029

Gibson, R.S., F. Yeudall, F. Drost, B. Mtitimuni and T. Cullinan. 1998. Dietary interventions to prevent zinc deficiency. Am. J. Clin. Nutr., 68: 484-493. https://doi.org/10.1093/ ajcn/68.2.484S

Hafeez, B., M. Khanif and M. Saleem. 2013. Role of zinc in plant nutrition: A review. Am. J. Exp. Agric., 3(2): 374-391. https://doi.org/10.9734/ AJEA/2013/2746

Hassan, M.U., M. Aamer, M.U. Chattha, T. Haiying, B. Shahzad, L. Barbanti, M. Nawaz, A. Rasheed, A. Afzal, Y. Liu and H. Guoqin. 2020. The critical role of zinc in plants facing the drought stress. Agriculture, 10(9): 396. https:// doi.org/10.3390/agriculture10090396

Hassan, M.U., M.U. Chattha, A. Ullah, I. Khan, A. Qadeer, M. Aamer, A.U. Khan, F. Nadeem and T.A. Khan. 2019. Agronomic biofortification to improve productivity and grain $\mathrm{Zn}$ concentration of bread wheat. Int. J. Agric. Biol., 21: 615-620.

Hussain, S., A.M. Muhammad and Rahmatullah. 2012. Increasing grain zinc and yield of wheat for developing world. A review. Emir. J. Food Agric., 22: 326-339. https://doi.org/10.9755/ ejfa.v22i5.4821

Holloway, R.E., R.D. Graham, T.M. McBeath and D.M. Brace. 2010. The use of a zinc efficient wheat cultivar as an adaptation to calcareous subsoil: a glasshouse study. Plant Soil, 336: 
15-24. https://doi.org/10.1007/s11104-0100435-X

Harris, D., A. Rashid, G. Miraj, M. Arif and M. Youna. 2007. On farm seed priming with zinc in chickpea and wheat. Plant Soil, 306: 3-10. https://doi.org/10.1007/s11104-007-9465-4

Hotz, C. and R.S. Gibson. 2007. Traditional foodprocessing and preparation practices to enhance the bioavailability of micronutrients in plantbased diets. J. Nutr., 137: 1097-1100. https:// doi.org/10.1093/jn/137.4.1097

Hotz, C. and K.H. Brown. 2004. Assessment of the risk of zinc deficiency in populations and options for its control. Food Nutr. Bull., 25: S91-S204.

Hoque, K.M. and H.J. Binder. 2006. Zinc in the treatment of acute diarrhea: Current status and assessment. Gastroent, 130(7): 2201-2205. https://doi.org/10.1053/j.gastro.2006.02.062

Imtiaz, M., 1999. Zn deficiency in cereals. $\mathrm{PhD}$ Thesis Reading University, U.K.

Johnson, S.E., J.G. Lauren, R.M. Welch and J.M. Duxbury. 2005. A comparison of the effects of micronutrient seed priming and soil fertilization on the mineral nutrition of chickpea (Cicer arietinum), lentil (Lens culinaris), rice (Oryza sativa) and wheat (Triticum aestivum) in Nepal. Exp. Agric., 41: 427-448. https://doi. org/10.1017/S0014479705002851

Kalayci, M., B. Torun, S. Eker, M. Aydin, L. Ozturk and I. Cakmak. 1999. Grain yield, zinc efficiency and zinc concentration of wheat cultivars grown in a zinc-deficient calcareous soil in field and greenhouse. Field Crop Res., 63: 87-98. https:// doi.org/10.1016/S0378-4290(99)00028-3

Kiekens, L., 1995. Zinc in Heavy Metals. In: B.J. Alloway (Ed.). Soils.London: Blackie Academic and Professional. https://doi.org/10.1007/97894-011-1344-1_13

Katyal, J.C. and N.S. Randhawa. 1983. Micronutrients FAO fertilizer and plant nutrition bullet in 7. Rome: Food and Agriculture Organization of the United Nations.

Kang, B.T. and E.G. Okoro. 1976. Response of flooded rice grown on a vertisol from northern Nigeria to zinc sources and methods of application. Plant Soil, 44: 15-25. https://doi. org/10.1007/BF00016951

Kumssa, D.B., E.J. Joy, E.L. Ander, M.J. Watts, S.D. Young, S. Walker and M.R. Broadley. 2015. Dietary calcium and zinc deficiency risks are decreasing but remain prevalent. Sci. Rep., 5: 1-11. https://doi.org/10.1038/srep10974

Loneragan, J.F. and M.J. Webb. 1993. Interactions between zinc and other nutrients affecting the growth of plants.In: Robson, A.D.(Ed.), Zinc in Soils and Plants. Kluwer Academic Publishers. Dordrecht, The Netherlands. https://doi. org/10.1007/978-94-011-0878-2_9

Maret, W. and H.H. Sandstead. 2006. Zinc requirements and the risks and benefits of zinc supplementation. J. Trace Elem. Med. Biol., 20: 3-18. https://doi.org/10.1016/j. jtemb.2006.01.006

Mousavi, S.R., 2011. Zinc in crop production and interaction with phosphorus. Aust. J. Basic Appl. Sci., 5: 1503-1509.

Maralian, H., 2009. Effect of foliar application of zinc and iron on wheat yield and quality. Afr. J. Biotechnol., 8: 6795-6798.

Ma, G., Y. Jin, Y. Li, F. Zhai, F.J. Kok, E. Jacobsen and X. Yang. 2008. Iron and zinc deficiencies in China: what is a feasible and cost-effective strategy. Publ. Health Nutr., 11: 632-638. https://doi.org/10.1017/S1368980007001085

Marı, J.B., S. Salgueiro, B. Marcela, E. Zubillaga, B.S. Alexis, A. Lysionek, R. Ricard, S. Weill and J.S. Boccio. 2002. The role of zinc in the growth and development of children. Nutrion, 18: 510-519. https://doi.org/10.1016/S08999007(01)00812-7

Maret, W., 2013. Zinc biochemistry: From a single zinc enzyme to a key element of life. Adv. Nutr., 4(1): 82-91. https://doi.org/10.3945/ an.112.003038

Marschner, H., 1995. Boron. In: Mineral nutrition of higher plants. $2^{\text {nd }}$ Edition. San Diego Acadmic Press.

Martens, D.C. and D.T. Westermann. 1991. Fertilizer application for correcting micronutrient defciences. In: Micronutrients in Agriculture. $2^{\text {nd }}$ Edition.

Mordtvedt, J., J. Cox, L.M. Shuman and R.M. Welch. 1991. Soil Sci. Soc. Am. Book Ser. No. 4 549-592.

Moraghan, J.T. and H.J. Mascagni. 1991. Environmental and soil factors affecting micronutrient deficiencies and toxicities. In: Mordvedt, J.J., Cox, F.R., Shumann, L.M., Welch, R.M. (Eds.), Micronutrients in Agriculture. Soil Science Society of America.

Mikkelsen, D.S. and K. Shiou. 1977. Zinc 
fertilization and behaviour in flooded soils. Spec. Publ. No. 5 Comm. Agric. Bur., Farnham Royal. Mineral Stresses, In A.R. Yeo and T.J. Flowers (ed). Approaches to Crop Improvement. pp. 59. Ning, P., S. Wang, P. Fei, X. Zhang, J. Dong, J. Shi and X.Tian.2019. Enhancing zinc accumulation and bioavailability in wheat grains by integrated zinc and pesticide application. Agron., 9(9):530. https://doi.org/10.3390/agronomy9090530

Norvell, W.A. and R.M. Welch. 1993. Growth and nutrient uptake by barley: Studies using an $\mathrm{N}$ (2- Hydroxyethyle) ethylenedinitrilotriacetic acid buffered nutrient solution technique. Zinc ion requirements. Plant Physiol., 101: 619-625. https://doi.org/10.1104/pp.101.2.619

Obrador, A., J. Novillo and J.M. Alvarez. 2003. Mobility and availability to plants of two zinc sources applied to a calcareous soil. Soil Sci. Soc. Am., 67: 564-572. https://doi.org/10.2136/ sssaj2003.5640

Oghbaei, M. and J. Prakash. 2016. Effect of primary processing of cereals and legumes on its nutritional quality: A comprehensive review. Cogent Food Agric., 2(1): 1136015. https:// doi.org/10.1080/23311932.2015.1136015

Olsen, S.R., 1972. Micronutrient Interactions. In: J.M. Mortved, J.J. Goirdano and W.L. Lindsaym (eds). Micronutrients in Agriculture. Soil Sci. Soc. Am. Madison, WI.

Ortiz, R., R.M. Trethowan, G. Ortiz, M. Ferrara, J.H. Iwanag, J.H. Dodds, J. Crouch, Crossa and H.J. Braun. 2007. High yield potential, shuttle breeding and a new international wheat improvement strategy. Euphytica, 157: 365384. https://doi.org/10.1007/s10681-0079375-9

Ozkan, H., A. Brandolini, A. Torun, S. Altintas, S. Eker and B. Kilian. 2006. Natural variation and identification of microelements content in seeds of Einkorn Wheat (Triticum monococcum). In: Proceedings of the $7^{\text {th }}$ International Wheat Conference, 27 November 2 December 2005, Mar del Plata, Argentina.

Parlak, M. and A.O. Parlak. 2011. Effect of soil compaction on root growth and nutrient uptake of forage crops. J. Food Agric. Environ., 9: 275278.

Peleg, Z., I. Cakmak, L. Ozturk, A. Yazici, Y.Jun, H. Budak, A.B. Korol, T. Fahima and Y. Saranga. 2009. Quantitative trait loci conferring grain mineral nutrient concentrations in durum wheat $\times$ wild emmer wheat RIL population. Theor. Appl. Gen., 119: 353-369. https://doi. org/10.1007/s00122-009-1044-Z

Prasad, A.S., 2008. Clinical, anti-inflammatory and antioxidant role of zinc. Exp. Gero., 43:370-377. https://doi.org/10.1016/j.exger.2007.10.013

Pfeiffer, W.H. and B. McClafferty. 2007. Harvest Plus: Breeding crops for better nutrition. Crop Sci., 47: 88-105. https://doi.org/10.2135/ cropsci2007.09.0020IPBS

Pandey, N., G.C. Pathak and C.P. Sharma. 2006. Zinc is critically required for pollen function and fertilisation in lentil. J. Trace Elem. Med. Biol., 20: 89-96. https://doi.org/10.1016/j. jtemb.2005.09.006

Pedler, J.F., D.R. Parker and D.E. Crowley. 2000. Zinc Deficiency-induced phytosiderophore release by the Triticaceae is not consistently expressed in solution culture. Planta, 211: 120 126. https://doi.org/10.1007/s004250000270

Pendias, A.K. and H. Pendias. 1992. Trace elements in soil and plants ( $2^{\text {nd }}$ edition). CRC Press, Boca Raton, Florida.

Qu, L.Q. T. Yoshihara, A. Ooyama, F. Goto and F. Takaiwa. 2005. Iron accumulation does not parallel the high expression level of ferritin in transgenic rice seeds. Planta, 222: 225-233. https://doi.org/10.1007/s00425-005-1530-8

Rashid, A. and J. Ryan. 2008. Micronutrients constrains to crop production in soils with Mediterranean-type characteristics. J. Plant Nutr., 27: 959-975. https://doi.org/10.1081/ PLN-120037530

Rehman, H.U., T. Aziz, M. Farooq, A. Wakeel and Z. Rengel. 2012. Zinc nutrition in rice production systems: A review. Plant Soil, 361(1-2): 203-226. https://doi.org/10.1007/ s11104-012-1346-9

Rengel, Z., G.D. Batten and D.E. Crowley. 1999. Agronomic approaches for improving the micronutrient density in edible portions of field crops. Field Crops Res., 60: 27-40. https://doi. org/10.1016/S0378-4290(98)00131-2

Rengel, Z. and R.B. Graham. 1995. Importance of seed zinc content for wheat growth on zinc- deficient soil. I. Vegetative growth. Plant Soil, 173: 259-266. https://doi.org/10.1007/ BF00011463

Renkou, X., A. Zhao, Q. Li, X. Kong and G. Ji. 2003. Acidity regime of the Red Soils in a subtropical region of southern China under field 
conditions. Geoderma, 115: 75-84. https://doi. org/10.1016/S0016-7061(03)00077-6

Sadeghzadeh, B., 2013. A review of zinc nutrition and plant breeding.J. Soil Sci.Plant Nutr., 13(4): 905-927. https://doi.org/10.4067/S071895162013005000072

Sarwar, S., E. Rafique, S.M. Gill and M.Z. Khan. 2017. Improved productivity and zinc content for maize grain by different zinc fertilization techniques in calcareous soils. J. Plant Nutr., 40(3): 417-426. https://doi.org/10.1080 /01904167.2016.1245322

Shahid, H., M.A. Maqsood and Rahmatullah. 2010. Increasing grain zinc and yield of wheat for the developing world: A review. Emir. J. Food Agric., 22 (5): 326-339. https://doi. org/10.9755/ejfa.v22i5.4821

Shewry, P.R., 2009. Wheat. J. Exp. Bot., 60: 15371553. https://doi.org/10.1093/jxb/erp058

Singh, M.V., 2007. Efficiency of seed treatment for ameliorating zinc deficiency in crops. In: Zinc Crops 2007, improving crop production and human health, 24-26 May, 2007, Istanbul, Turkey.

Skrovanek, S., K. DiGuilio, R. Bailey, W. Huntington, R. Urbas, B. Mayilvaganan, G. Mercogliano and J.M. Mullin. 2014. Zinc and gastrointestinal disease. World J. Gastrointest. Pathophysiol., 5(4): $496 . \quad$ https://doi. org/10.4291/wjgp.v5.i4.496

Soltangheisi, A., Z.A. Rahman, C.F. Ishak, H.M. Musa and H. Zakikhani. 2014. Interaction effects of phosphorus and Zinc on their uptake and 32P absorption and translocation in sweet corn (Zea mays) grown in a tropical soil. Asian J. Plant Sci., 13(3): 129-135. https://doi. org/10.3923/ajps.2014.129.135

Stein, A.J., P. Nestel, J.V. Meenakshi, M. Qaim, H.P.S. Sachdev and Z.A. Bhutta. 2007. Plant breeding to control zinc deficiency in India: How cost-effective is biofortification? Pub. Health Nutr., 10: 492-501. https://doi. org/10.1017/S1368980007223857

Singh, B., S.K.A. Natesan, B.K. Singh and K. Usha. 2005. Improving zinc efficiency of cereals under zinc deficiency. J. Curr. Sci., 88: 36-44.

Slaton, N.A., E.E. Gbur, C.E. Wilson and R.J. Norman. 2005. Rice response to granular zinc sources varying in water-soluble zinc. Soil Sci. Soc. Am. J., 69: 443-453. https://doi. org/10.2136/sssaj2005.0443
Savithri, P., R. Pernmal and R. Nagarajan. 1999. Soil and crop management technologies for enhancing rice production under micronutrient constrains. Nutr. Cycling Agroecosyst., 53: 4383. https://doi.org/10.1007/978-94-011-50781_8

Schachtman, D.P. and S.J. Barker. 1999. Molecular approaches for increasing the micronutrient density in edible portions of food crops. Field Crop Res., 60: 81-92. https://doi.org/10.1016/ S0378-4290(98)00134-8

Shankar, A.H. and A.S. Prasad. 1998. Zinc and immune infection: The biology of altered resistance to infection. Am. J. Clin. Nutr., 68: 447-463. https://doi.org/10.1093/ ajcn/68.2.447S

Schwartz, S.M., R.M. Welch, D.L. Grunes, E.E. Cary, W.A. Norvell, M.D. Gilbert, M.P. Meridith and C.A. Sauchirico. 1987. Effect of zinc, phosphorus and root-zone temperature on nutrient uptake by barley. Soil Sci. Soc. Am. J., 51: 371-375. https://doi.org/10.2136/ sssaj1987.03615995005100020021x

Singh, J.P., R.E. Karamonas and J.W.B. Stewart. 1986. Phosphorus-induced zinc deficiency in wheat on residual phosphorus plots. Agron. J., 78: 668-675. https://doi.org/10.2134/agronj19 $86.00021962007800040023 x$

Singh, M.V. and I.P. Abrol. 1986. Transformation and movement of zinc in an alkali soil and their influence on the yield and uptake of zinc by rice and wheat crops. Plant Soil, 94: 445-449. https://doi.org/10.1007/BF02374338

Taheri, N., H. Heidari, K. Yousefi and S.R. Mousavi. 2011. Effect of organic manure with phosphorus and zinc on yield of seed potato. Austr. J. Basic Appl. Sci., 5(8): 775-780.

Tiwari, V.K., N. Rawat, P. Chhuneja, K. Neelam, R. Aggarwal, G.S. Randhawa, H.S. Dhaliwal, B. Keller and K. Singh. 2009. Mapping of quantitative trait loci for grain iron and zinc concentration in diploid A genome wheat. J. Hered., 100: 771-776. https://doi.org/10.1093/ jhered/esp030

Trethowan, R.M., 2007. Breeding wheat for high iron and zinc at CIMMYT: State of the art, challenges and future prospects. In: Proceeding of the $7^{\text {th }}$ International Wheat Conference. Mar del Plata, Argentina.

Trethowan, R.M., M.P. Reynolds, K.D. Sayre and I. Ortiz-Monasterio. 2005. Adapting wheat 
cultivars to resource conserving farming practices and human nutritional needs. Ann. Appl. Biol., 146: 404-413. https://doi.org/10.1111/j.17447348.2005.040137.x

Tisdale, S.L., W.L. Nelson and J.D. Beaten. 1984. Zinc in soil fertility and fertilizers. $4^{\text {th }}$ edition Micmillion Publishing Company, New York.

Uauy, C., A. Distelfeld, T. Fahima, A. Blechl and J. Dubcovsky. 2006. A NAC gene regulating senescence improves grain protein, zinc, and iron content in wheat. Science, 314: 1298-1301. https://doi.org/10.1126/science.1133649

Viets, F.G., L.C. Boawn and C.L. Crawford. 1957. The effect of nitrogen and types of nitrogen carrier on plant uptake indigenous and applied zinc. J. Soil Sci. Soc. Am., 21: 197-206. https://doi.org/10.2136/ sssaj1957.03615995002100020016x

Wang, L.C. and S. Busbey. 2005. Images in clinical medicine. Acquired acrodermatitis enteropathica. N. Eng. J. Med., 352: 1121. https://doi.org/10.1056/NEJMicm030844

White, P.J. and M.R. Broadley. 2005. Biofortifying crops with essential mineral elements. Trends Plant Sci., 10: 586-593. https://doi. org/10.1016/j.tplants.2005.10.001

Welch, R.M. and R.D. Graham. 2004. Breeding for micronutrients in staple food crops from a human nutrition perspective. J. Exp. Bot., 55(396): 353-364. https://doi.org/10.1093/jxb/ erh064

Wessells, K.R. and K.H. Brown. 2012. Estimating the global prevalence of zinc deficiency: results based on zinc availability in national food supplies and the prevalence of stunting. PLoS One, 7: e50568. https://doi.org/10.1371/ journal.pone.0050568

WHO, 2002. World health report. 2002. Reducing Risks, Promoting Healthy Life. World Health Organization, Geneva, Switzerland.

White, J.G. and R.J. Zasoski. 1999. Mapping soil micronutrients. Field Crop Res., 60: 11-26. https://doi.org/10.1016/S03784290(98)00130-0

Xie, W. and E. Nevo. 2008. Wild emmer: Genetic resources, gene mapping and potential for wheat improvement. Euphytica, 164: 603-614. https://doi.org/10.1007/s10681-008-9703-8

Xie, X. and M. Tang. 2019. Interactions between phosphorus, zinc and iron homeostasis in nonmycorrhizal and mycorrhizal plants. Front.
Plant Sci., 10: 1172. https://doi.org/10.3389/ fpls.2019.01172

Yue-Qiang, Z., Y. Sun, Y. Ye, M. Karim, Y. Xue, P. Yan, Q. Meng, Z. Cui, I. Cakmak, F. Zhang and C. Zou. 2012. Zinc biofortification of wheat through fertilizer applications in different locations of China. Field Crops Res., 125: 1-7. https://doi.org/10.1016/j.fcr.2011.08.003

Yang, X.W., X. Tain, X. Lin, Y. Co and Z. Chen. 2011. Impacts of phosphorus and zinc levels on phosphorus and zinc nutrition and phytic acid concentration in wheat. J. Sci. Food Agric., 91(13): 2322-2328. https://doi.org/10.1002/ jsfa.4459

Yadav, R.S., A.M. Patel, N. Dodia, A.V. Aglodiya, G.A. Patel and N. Augustin. 2011. Agronomic bio-fortification of wheat (Triticum aestivum L.) through iron and zinc enriched organics. J. Wheat Res., 3(1): 46-51.

Yilmaz, A.H., I. Ekiz, B. Gültekin, H. Torun, S. Barut, K. Karanlik and I. Cakmak. 1998. Effect of seed zinc content on grain yield and zinc concentration of wheat grown in zinc-deficient calcareous soils. J. Plant Nutr., 21: 2257-2264. https://doi.org/10.1080/01904169809365559

Yilmaz, A., H. Ekiz, B. Torun, I. Gultekin, S. Karanlik, S.A. Bagci and I. Cakmak. 1997. Effect of different zinc application methods on grain yield and zinc concentration in wheat grown on zinc-deficient calcareous soils in Central Anatolia. J. Plant Nutr., 20: 461-471. https://doi.org/10.1080/01904169709365267

Zhang, Y.Q. Y.X. Sun, L.Y. You, R. Karim, Y.F. Xue, P. Yan, Q.F. Meng, Z.L. Cui, I. Chamak, F.S. Zhang and C.Q. Zou. 2012. Zinc biofortification of wheat through fertilizer applications in different locations of China. Field Crop Res., 125: 1-7. https://doi.org/10.1016/j. fcr.2011.08.003

Zou, C.Q. Y.Q. Zhang, A. Rashid, E. Savasli, R.Z. Arisoy, I. Ortiz-Monasterio, S. Simunji, Z.H. Wang, V. Sohu, M. Hassan, Y. Kaya, O. Onder, O. Lungu, M.Y. Majid, A.K. Joshi, Y.Zelenskiy, F.S. Zhan and I. Cakmak. 2012. Biofortification of wheat with zinc through zinc fertilization in seven different countries. Plant Soil, pp. 104-116. https://doi.org/10.1007/s11104-0121369-2

Zhao, F.J., Y.H. Su, S.J. Dunham, M. Rakszegi, Z. Bedo and S.P. McGrath. 2009. Variation in mineral micronutrient concentrations in 
grain of wheat lines of diverse origin. J. Cereal Sci., 49: 290-295. https://doi.org/10.1016/j. jcs.2008.11.007

Zhang, Y., R. Shi, K.M. Rezaul, F. Zhang and C. Zou.2010.Iron and zinc concentrations in grain and flour of winter wheat as affected by foliar application. J. Agric. Food Chem., 58: 1226812274. https://doi.org/10.1021/jf103039k

Zhao, F.J. and S.P. McGrath. 2009. Bio fortification and phytoremediation. Curr. Opin. Plant Biol., 12: 373-380. https://doi.org/10.1016/j. pbi.2009.04.005 